\title{
EVIDENCE ON THE INSURANCE EFFECT OF REDISTRIBUTIVE TAXATION
}

\author{
Charles Grant, Christos Koulovatianos, Alexander Michaelides, and Mario Padula*
}

Abstract - If households face uninsurable idiosyncratic earnings risk, theory predicts that redistributive tax and transfer systems have both an insurance and a distortionary effect. Exploiting the substantial variation of tax and transfer systems across U.S. states and over time, we investigate the necessary traces of these two effects in the data: that state-level measures of redistributive taxation should correlate negatively with the standard deviation and the mean of the within-state consumption distribution. We find that the first correlation is robust, supporting strongly the presence of an insurance effect. The distortionary effect can also be detected in the data, but it is less precisely estimated.

\section{Introduction}

$\mathrm{M}$ $\mathrm{UCH}$ analysis of household consumption focuses on the study of choices made by forward-looking wealthaccumulating agents who face undiversifiable idiosyncratic labor income shocks and liquidity constraints. ${ }^{1}$ Incorporating this partial-equilibrium consumer problem into workable simulation and calibration models of the macroeconomy that explicitly allow heterogenous agents has become standard ever since the pioneering work by Bewley (1986), Huggett (1993), and Aiyagari (1994). Critical policy issues arise from the inclusion of idiosyncratic risk. In these macromodels of uninsurable idiosyncratic risk, markets are incomplete, and agents face the probability of not being able to smooth consumption through borrowing. Hence distortionary income taxes might improve aggregate welfare, because such taxes directly compress the spread of uncorrelated idiosyncratic income shocks a priori. In other words, marginal income taxes may have an insurance effect by decreasing the effective fluctuations of after-tax individual income, a point also made in earlier work by Mirrlees (1974) and Varian (1980). Consistent with these ideas, Conesa, Kitao, and Krueger (2008) calibrate a heterogeneous agent model with idiosyncratic risk and find that optimal marginal income tax rates are positive and sizable.

In any idiosyncratic earnings risk model where consumer goods are normal, with or without labor or savings distortions, the insurance effect of redistributive taxation would imply

Received for publication February 22, 2007. Revision accepted for publication April 9, 2009.

* Grant: University of Reading; Koulovatianos: University of Nottingham and CFS; Michaelides: LSE and CEPR; Padula: University "Ca' Foscari" of Venice and CSEF.

We thank Reza Baqir, Chris Carroll, Antonio Fatas, Gerhard Glomm, Michael Haliassos, Tullio Jappelli, Ilian Mihov, Roberto Perotti, Torsten Persson, Stephen Pischke, Assaf Razin, Victor Ríos-Rull, Harald Uhlig, Fabrizio Zilibotti, and participants at the CEPR Dynamic Fiscal Policy Conference and the EUI for comments on a very early draft. We also thank the editor and two anonymous referees for comments and suggestions and Tim Storey at the National Conference of State Legislatures for providing data on state political affiliations. All errors remain our own.

${ }^{1}$ For example, Deaton (1991); Carroll (1997); Hubbard, Skinner, and Zeldes (1995); and Gourinchas and Parker (2002) offer supporting evidence that some combination of precautionary saving or liquidity constraints can be important determinants of saving and consumption dynamics. that higher taxes and transfers decrease the standard deviation of consumption across households. ${ }^{2}$ However, average consumption may be lower due to reduced incentives for capital accumulation or labor supply. The traditional approach without idiosyncratic risk has emphasized the distortionary effect of taxes-the reduction in average consumption that decreases welfare. The more recent literature, in which agents face uninsured idiosyncratic risk, demonstrates the insurance effect of redistributive taxes, a reduction in each household's consumption variability that may raise welfare. ${ }^{3}$ The relative importance of these two effects is crucial when evaluating the welfare effects of fiscal policy. Nevertheless, assessing whether the distortionary and insurance effects of redistribution through the tax and benefit system can indeed be observed in the data remains an open question. Testing for the presence of these effects is therefore the aim of this study.

We examine the empirical evidence on the effect of taxes and transfers on the mean and the standard deviation of consumption across households in order to investigate the traces of the distortionary and the insurance effect in consumption. Demonstrating empirically these effects, however, is not a trivial task: it requires using household data to construct measures of the tax system and the distribution of consumption. One possibility is to investigate households in different countries. However, we believe that cross-country variation in the key variables may reflect differences in institutional, cultural, and other country-specific features, as well as differences in the measurement of the appropriate household level variables in different national surveys. Moreover, the design of these household surveys differs substantially among countries, making it difficult to construct consistent measures of consumption and of the tax system across countries.

Rather than using differences across countries, we exploit differences across U.S. states and over time to investigate the relationship within each state between consumption and the tax system. The difficulties highlighted above are likely to be much less important for U.S. states since, in measuring taxes or consumption, the same survey can be exploited for all households in the sample. Using the same survey across tax regimes reduces the chance that differences in survey design spuriously generate the different measured policy responses. However, there are two obvious disadvantages. First, relatively few households will be used in each state in measuring the tax system or the distribution of consumption for that state; hence, such state-level measures are likely to be contaminated by measurement error. Second, households find it easier to move between U.S. states than between countries.

\footnotetext{
${ }^{2} \mathrm{~A}$ transfer system is not necessary for higher marginal taxation to generate a more compressed distribution. Elmendorf and Kimball (2000) show in a partial equilibrium model how realistic increases in labor income marginal tax rates can cause large reductions in after-tax labor income risk.

${ }^{3}$ Floden (2001) provides a clear evaluation of the welfare effects showing the trade-off between distortions and insurance.
} 
Both problems are likely to make it more difficult to demonstrate the effects of redistributive taxes on the distribution of consumption. Nevertheless, using data on U.S. states has a major advantage in that it allows us to exploit the surprisingly large variation in tax regimes between states and over time. This makes the United States an appropriate laboratory in which to test the effect of taxes on consumption.

Our empirical investigation necessitates constructing measures of consumption and of taxes for different states. For consumption, we use 24 years from the American Consumer Expenditure Survey (CEX). The data allow us to compute the mean and the standard deviation of log nondurable consumption by year and state. To construct the tax measures, we first collect household income data from the Current Population Survey (CPS) and then use the TAXSIM model. This program, provided by the NBER, takes inputs about each household's income and other characteristics to construct the state and the federal tax liability, as well as the marginal tax rates, of each household in the data (full details on the TAXSIM model can be found in Feenberg \& Coutts, 1993). From the TAXSIM output, we construct two different measures of the tax system in each state. One is the mean marginal tax rate across households in each state and each year. However, this measure of taxes has serious drawbacks as a measure of redistributiveness: it ignores tax progressivity as well as transfers. We therefore also construct a measure of tax redistribution that reflects the compression of the income distribution induced by both taxes and transfers. We report results for both measures of the tax system, although, as will be discussed further below, we prefer the measure of redistributive taxation.

The empirical exercise investigates the relationship between redistributive taxation and consumption. We find evidence that more redistributive taxes are negatively correlated with the standard deviation of (log) nondurable consumption. The conclusions are robust to unobserved heterogeneity at the state level and to expanding the specification to include variables that vary both across states and over time, such as the state unemployment rate. The results are unchanged when we address the possible endogeneity of our tax measure by using appropriate instruments. We therefore find evidence supporting the presence of an insurance effect of redistributive taxation in the United States.

Our results also suggest evidence for the distortionary effect of higher taxes, although the negative correlation of redistributive taxes with state-level mean consumption is not as robust as the correlation concerning the insurance effect. Nevertheless, after controlling for state effects, the results are always significant when using the mean marginal tax rate and the income compression measure of taxes if the tax system is appropriately instrumented. Demonstrating the insurance effect means it is important to stress the appropriate policy trade-offs (between the distortionary and insurance effects) in models of taxes that incorporate idiosyncratic risk.

The structure of the paper is as follows. In section II, we describe the data and compare the tax system in different U.S. states. We present the empirical findings and provide robustness checks in section III, and make concluding remarks in section IV.

\section{Data}

Our empirical exercise exploits cross-state differences in the evolution of state taxation and its relationship to the distribution of consumption. To proceed, we need to measure the mean and standard deviation of household consumption within each state and each year, and also to measure tax redistributiveness for those states. In turn, this requires measuring each household's consumption, income, and taxes using household-level data. To construct a reasonably homogeneous sample of households across the different states, we select prime-age households (where the head is between the ages of 30 and 60) and exclude self-employed and farming households.

\section{A. Consumption}

We use CEX data from 1982 to 2005 to measure household nondurable consumption. The CEX is a household-level survey run on a yearly basis by the U.S. Bureau of Labor Statistics (BLS) for computing the weights for the American Consumer Price Index. The CEX has detailed information on individual expenditure items, as well as on a variety of household characteristics (including state of residence). This allows us to construct a measure of nondurable consumption that includes food and beverages, tobacco, housekeeping services, fuel, public utilities, repairs, public transport, personal care, entertainment, clothing, and books. Households are interviewed four times and report their expenditures in the three months before the interview month. To minimize the recall error, we keep only the expenditure for the month closest to the interview month. More details on the CEX survey can be found in Attanasio, Battistin, and Ichimura (2005). ${ }^{4}$ We restrict the sample to households for which full state information is available. ${ }^{5}$ In order to keep the sampling error low, we include only the 22 largest states - those states with, on average, 80 observations per year.

Consumption is deflated by the (region-specific) CPI in order to convert nominal values into real ones. Finally, to control for cross-state differences in demographic composition, we regress nondurable consumption on a cubic polynomial in age, education, family size, race, and marital status and construct group averages from the residuals.

\footnotetext{
${ }^{4}$ However, see the Online Appendix, available at http://www.mitpress journals.org/doi/suppl/10.1162/REST_a_00040, for regression analysis that includes all three months to which the interview refers, showing the results are broadly similar if that specification is used instead.

${ }^{5}$ By comparing the sample for which we have state information with the sample for which we do not have state information, we find that the share of male household heads in the missing state information sample is comparable to that in the nonmissing information sample (71 versus 70 percent). Moreover, in both subsamples, the average age is 47.5 , the family size 2.5 persons, and the number of children 0.7 .
} 
TABLE 1.-WAGES AND TRANSFERS FOR U.S. HOUSEHOLDS, 1982-2005

\begin{tabular}{|c|c|c|c|}
\hline & Average & $\begin{array}{c}\text { Average If } \\
\text { Received }\end{array}$ & $\%$ Receive \\
\hline Wages & $\$ 30,350$ & $\$ 32,922$ & 92.2 \\
\hline Social security & 289 & 5,303 & 5.9 \\
\hline Supplementary security income & 81 & 3,210 & 3.0 \\
\hline Public assistance, welfare & 107 & 2,916 & 4.2 \\
\hline \multicolumn{4}{|l|}{ Unemployment, workers' } \\
\hline compensation & 275 & 2,491 & 11.5 \\
\hline Food stamps & 71 & 1,128 & 6.8 \\
\hline Total transfer & 833 & 3,771 & 22.2 \\
\hline \multicolumn{4}{|c|}{$\begin{array}{l}\text { Data are constructed from reported responses in the March supplement of the CPS for the year } \\
\text { 1982-2005. Total transfer refers to the sum of social security benefits, supplementary security benefits } \\
\text { unemployment or workers' compensation, welfare or other public assistance, and food stamps. The CP } \\
\text { questionnaire conflates social security benefits with railroad retirement income and worker's compensatio } \\
\text { qith veter }\end{array}$} \\
\hline
\end{tabular}

\section{B. Income and Transfers}

To measure how much redistribution there is through the tax system, household-level information on both income and transfers is required. This information is obtained from the March supplement of the CPS. This survey, also run by the BLS, is designed to give detailed and accurate information on income and demographics. Using income (and transfer) data from the CPS has several advantages. First, the survey asks much more detailed questions on income than does the CEX. Second, more households are surveyed, making state-level averages more accurate. Third, in the regressions, we will have consumption measures on the left-hand side and income and tax measures on the right-hand side: taking the income and consumption measures from different surveys ensures that measurement errors in these variables are uncorrelated.

Using the CPS, we construct total household labor income and transfer income, which includes social security and railroad retirement income, supplementary security income, unemployment compensation, worker's compensation and veterans' payments, public assistance or welfare, and the value of food stamps received. 6 The data, summarized in table 1 , show that the average transfer over the whole sampled population of non-self-employed, nonfarming prime-age households amounts to $\$ 883$. Moreover, $22.2 \%$ of households receive some sort of transfer. Conditional on receiving at least something, households receive an average of $\$ 3,771$. This should be compared to the average household salary in the survey of $\$ 30,350$, or $\$ 14,916$ for households that are receiving transfers. While this amount may seem small, it can make a substantial difference to some households' after-tax (and transfer) income.

\section{Household Taxes}

U.S. households pay taxes on earned and unearned income, as well as sales and property taxes. We concentrate on income taxes, which are raised at both the state and the federal levels, and exclude sales and property taxes. Sales taxes are paid

\footnotetext{
${ }^{6}$ While there is some evidence that unearned income is underreported in the CPS (see Ruser, Pilot, \& Nelson, 2004), we believe this problem is unlikely to seriously distort the results in this study since it is likely to affect residents in all states equally.
}

at the place of sale rather than residence, making it difficult to measure the sales taxes levied on households within the state if cross-border shopping takes place. In the CEX, the spending figure excludes sales taxes, so that expenditure is comparable across states. Property taxes are largely levied at the county, school board, or city level. Therefore, the property tax legislation may be very diverse within each state depending on the locality where the households reside.

Constructing a single measure of tax redistributiveness in each state is not trivial and entails addressing a number of problems. ${ }^{7}$ Income tax systems can be complicated since not only do different households face different tax rates, but there is also considerable variation in tax rates across jurisdictions.

The first column of table 2 shows the lowest and the highest federal tax brackets for 2003, a representative year near the end of our sample period. The federal marginal tax rate varies nonlinearly from $10 \%$ for single people whose annual income is less than $\$ 7,000$ ( $\$ 14,000$ for married couples filing jointly) up to $35 \%$ for incomes over $\$ 311,950$, with additional tax brackets of $15 \%, 25 \%, 28 \%$, and $33 \%$ for single filers whose annual income is under $\$ 28,400, \$ 68,800$, and $\$ 143,500$ (with higher bracket limits for household heads and couples filing jointly). These tax rates and tax brackets have all changed over the years. Before 1987 a much larger number of tax brackets was applicable, and before 1996, around $15 \%$ to $20 \%$ of people had incomes that were not sufficiently high for them to pay any federal income tax.

In an early paper, Feenberg and Rosen (1987) document the large variation of tax regimes across states for 1977 to 1983. They show that in 1983, in all but four states there was no federal deduction for state income taxes paid, while in fifteen states the deduction for federal income taxes paid was allowed (in seven states within a limit). In fifteen states, couples and individuals had different schedules, and in seventeen income splitting was allowed.

The remaining rows of table 2 describe the variation in state tax rates in 2003 and demonstrate the large differences in state marginal tax rates and exemptions in different states. It shows that several states, including Texas, Florida, and Washington, do not levy any income taxes on their residents. The other states have a variety of income tax bands and exemptions (or tax credits) that are applicable. Although some states, such as Massachusetts and Illinois, have a flat-rate income tax, the marginal tax rate increases with income in most states. The difference between the highest and lowest marginal tax rate can sometimes be large. In Ohio the lowest marginal tax rate is $0.743 \%$ and the highest is $7.5 \%$, while several states have marginal tax rates even higher for the highest-earning households. There are also typically a variety of tax allowances to which households are entitled. While there is no tax-exempt income in Pennsylvania, up to $\$ 8,800$ of income is exempt

\footnotetext{
${ }^{7}$ We deliberately use the term redistributive rather than progressive as progressiveness is most often used to describe a tax system in which the marginal tax rate increases with income (or wealth). For example, a tax rate of $100 \%$, with lump-sum transfers, is not progressive, although it is highly redistributive.
} 
TABle 2.-Federal and Selected State Income Tax Rates

\begin{tabular}{|c|c|c|c|c|c|c|c|}
\hline \multirow[b]{2}{*}{ State } & \multicolumn{2}{|c|}{2003 Tax Rates } & \multicolumn{3}{|c|}{ Exemptions } & \multirow[b]{2}{*}{ Mean Tax Rate } & \multirow[b]{2}{*}{ Tax Redistribution } \\
\hline & Minimum & Maximum & Single & Married & Dependents & & \\
\hline Federal & 10 & 35 & & & & & \\
\hline Alaska $^{a}$ & & & & & & 18.9 & 22.8 \\
\hline Arizona & 2.87 & 5.04 & $\$ 2,100$ & $\$ 4,200$ & 2,300 & 22.3 & 30.0 \\
\hline California & 1.0 & 9.3 & $80^{\mathrm{b}}$ & $160^{\mathrm{b}}$ & $251^{\mathrm{b}}$ & 23.6 & 33.9 \\
\hline Colorado & 4.63 & 4.63 & & None & & 25.1 & 30.7 \\
\hline Florida $^{\mathrm{a}}$ & & & & & & 18.3 & 25.9 \\
\hline Georgia & 1.0 & 6.0 & 2,700 & 5,400 & 2,700 & 23.8 & 31.5 \\
\hline Illinois & 3.0 & 3.0 & 2,000 & 4,000 & 2,000 & 22.7 & 29.6 \\
\hline Indiana & 3.4 & 3.4 & 1,000 & 2,000 & 1,000 & 22.1 & 28.2 \\
\hline Maryland & 2.0 & 4.75 & 2,400 & 4,800 & 2,400 & 26.9 & 32.8 \\
\hline Massachusetts & 5.0 & 5.0 & 4,400 & 8,800 & 1,000 & 24.9 & 33.3 \\
\hline Michigan & 4.0 & 4.0 & 3,000 & 6,000 & 3,000 & 23.8 & 31.4 \\
\hline Minnesota & 5.35 & 7.85 & 3,000 & 6,000 & 3,000 & 27.4 & 34.4 \\
\hline Missouri & 1.5 & 6.0 & 2,100 & 4,200 & 2,100 & 22.9 & 30.0 \\
\hline New Jersey & 1.4 & 6.37 & 1,000 & 2,000 & 1,500 & 24.3 & 32.1 \\
\hline New York & 4.0 & 6.85 & - & - & 1,000 & 22.9 & 34.8 \\
\hline Ohio & 0.743 & 7.5 & 1,200 & 2,400 & 1,200 & 22.9 & 30.7 \\
\hline Oregon & 5.0 & 9.0 & $145^{\mathrm{b}}$ & $290^{\mathrm{b}}$ & $145^{\mathrm{b}}$ & 25.9 & 32.8 \\
\hline Pennsylvania & 2.8 & 2.8 & & None & & 21.2 & 29.0 \\
\hline Texas $^{\mathrm{a}}$ & & & & & & 18.2 & 26.6 \\
\hline Virginia & 2.0 & 5.75 & 800 & 1,600 & 800 & 25.8 & 31.3 \\
\hline Washington $^{\mathrm{a}}$ & & & & & & 20.0 & 24.9 \\
\hline Wisconsin & 4.6 & 6.75 & 700 & 1,400 & 400 & 27.0 & 33.0 \\
\hline 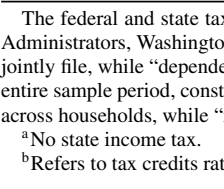 & $\begin{array}{l}\text { or 2003. The di } \\
\text { Minimum" and } \\
\text { rs to each addi } \\
\text { sing income fro } \\
\text { compression" re } \\
\text { exempt income }\end{array}$ & $\begin{array}{l}\text { eral taxes are } \\
\text { n" refer to the } \\
\text { endent person } \\
\text { ch supplemer } \\
\text { ninus the rati }\end{array}$ & $\begin{array}{l}\text { rom the In } \\
\text { and maxi } \\
\text { the file } \mathrm{m} \text {. } \\
\text { S for } 198 \\
\text { ndard devi }\end{array}$ & $\begin{array}{l}\text { ackets in the } \\
\text { he last two c } \\
\text { using taxes } \\
\text { ome after to }\end{array}$ & $\begin{array}{l}\text { partment of Tre } \\
\text { ngle" and "marr } \\
\text { port the mean n } \\
\text { from the NBER } \\
\text { transfers) to the }\end{array}$ & $\begin{array}{l}\text { re data on state taxes a } \\
\text { r to single filers and hol } \\
\text { ax rate and the tax redi } \\
\text { I program. "Mean tax r } \\
\text { deviation of income be }\end{array}$ & $\begin{array}{l}\text { able from the Federation } \\
\text { s in which the husband an } \\
\text { on measure for each state } \\
\text { ers to the mean marginal t } \\
\text { es. }\end{array}$ \\
\hline
\end{tabular}

from state income tax in Massachusetts for married couples, but only $\$ 1,000$ for each dependent - in contrast to Minnesota, which allows the same exempt level of income for the earner, the earner's partner, and each dependent.

To construct each household's income tax burden, we exploit the TAXSIM 8.0 program developed by Feenberg (see Feenberg \& Coutts, 1993, for details) and provided by the NBER. Using a variety of household variables taken from the CPS, including the husband's and wife's earnings, interest, dividends and other income, and information about the household's characteristics (such as the number of dependent children) and other deductibles (like property costs), as well as the year and state of residence, the program calculates the household's state and the federal tax liability, and the marginal tax rates, explicitly controlling for a variety of allowances. The output of the TAXSIM program allows us to measure how redistributive the tax system is in each state.

\section{Measuring Tax Redistributiveness}

No completely satisfactory measure of redistributiveness exists, but given the output provided by the TAXSIM program, several measures are possible. Rather than explicitly model all the different effective marginal tax rates (and transfers) that are available, we instead reduce the problem to constructing an index that summarizes the tax system in each state. One obvious measure is to compute the average marginal tax rate across households within each time period $t$ and state $j$. This is calculated as the mean of the household marginal (federal and state) tax rates obtained from the TAXSIM program. The second-to-last column of table 2 reports the average over the entire sample period of this tax measure for each of the states in our sample. The mean marginal tax rate for the whole of the United States (taking federal and state taxes together) is $23.3 \%$, but the differences across states are surprisingly large. The mean marginal tax rate in Texas and Florida, where there is no state income tax, is just over $18 \%$, but it is around $27 \%$ in Maryland and in Wisconsin. That is, taxes in the latter two states are $50 \%$ higher than in Florida.

The mean marginal tax rate, however, accounts for neither transfers nor heterogeneity among household tax rates. As we saw earlier, marginal taxes differ substantially across agents even within the same year and state. Furthermore, agents have many exemptions, allowances, and transfers available to them that depend on their household characteristics. Hence, the mean marginal tax rate does not adequately capture the progressivity of the tax system. For example, a mean marginal tax rate of $20 \%$ in a state could be due to all households paying a marginal tax rate of $20 \%$, or to the bottom fifth of the population paying $100 \%$ and the rest nothing, or to the top $20 \%$ paying $100 \%$ and the rest nothing. These three cases have substantially different implications for redistribution.

To address these concerns about using the mean marginal tax rate, we also construct a more direct measure of how much the tax system compresses or redistributes income, which explicitly accounts for transfers and for the fact that the marginal tax rate differs across households. This 
measure is similar to measures of government redistribution used by Attanasio and Ríos-Rull (2000) and Krueger and Perri (2006). This income compression measure is defined as

$$
1-\frac{s d_{j t}\left(\text { income }_{i j t}-\operatorname{tax} \text { liability }_{i j t}+\text { transfers }_{i j t}\right)}{s d_{j t}\left(\text { income }_{i j t}\right)},
$$

where the tax liability is obtained from the TAXSIM program and $i$ denotes the household. This measure is computed for households that reside in a given state $j$ in a given time period $t$ as 1 minus the ratio of the standard deviation of income after tax and transfers to the standard deviation of income before tax and transfers. ${ }^{8}$ Given that the mean marginal tax rate conceals large differences in households' marginal tax rates, the income compression measure will be our preferred measure of redistribution through the tax system. Moreover, it includes transfers that are ignored when measuring the tax system using the mean marginal tax rate.

The last column of table 2 reports the income compression measure of taxes for each of the states in our sample. The income compression measure of taxes varies substantially across the United States, as does the mean marginal tax rate. However, the income compression measure is consistently higher since it accounts transfers and tax progressivity. Nevertheless, the rank ordering of states is similar (the correlation between the two measures is 0.74 ). The lowest value in the continental United States for the income compression measure of taxes and transfers is in Washington at $24.9 \%$, while the highest value, at $34.8 \%$, is in New York (traditionally viewed as one of the states with the most progressive taxation). That is, the tax and transfer system is 50\% more redistributive in New York than in, for example, Florida. Taking both tax measures, the numbers in table 2 show that there is enough variation across states to get meaningful results, a key issue if we are to convincingly assess the theoretical predictions, and results are reported for both measures.

\section{The Empirical Evidence}

The substantial variation of tax regimes across U.S. states and over time allows us to show how the two measures of taxes are related to the mean and standard deviation of real nondurable log consumption (referred throughout as the mean and standard deviation of consumption). To control for observed heterogeneity at the household level, the following procedure was adopted: in the first stage, household consumption was regressed against a cubic polynomial in age,

\footnotetext{
8 Using variances instead of standard deviations in equation (1) can allow the decomposition of the variance of after-tax income into the variance of gross income, the variance of taxes, and the covariance between the two. However, we prefer the standard deviation measure in order to satisfy certain desirable requirements. For example, if everyone faces the same flat marginal tax rate with no allowances, it is plausible to require that the resulting measure be equal to this common marginal rate. Using the variance would violate this requirement.
}

FIgURE 1.-NONDURABLE CONSUMPTION AND REDISTRIBUTIVE TAXATION
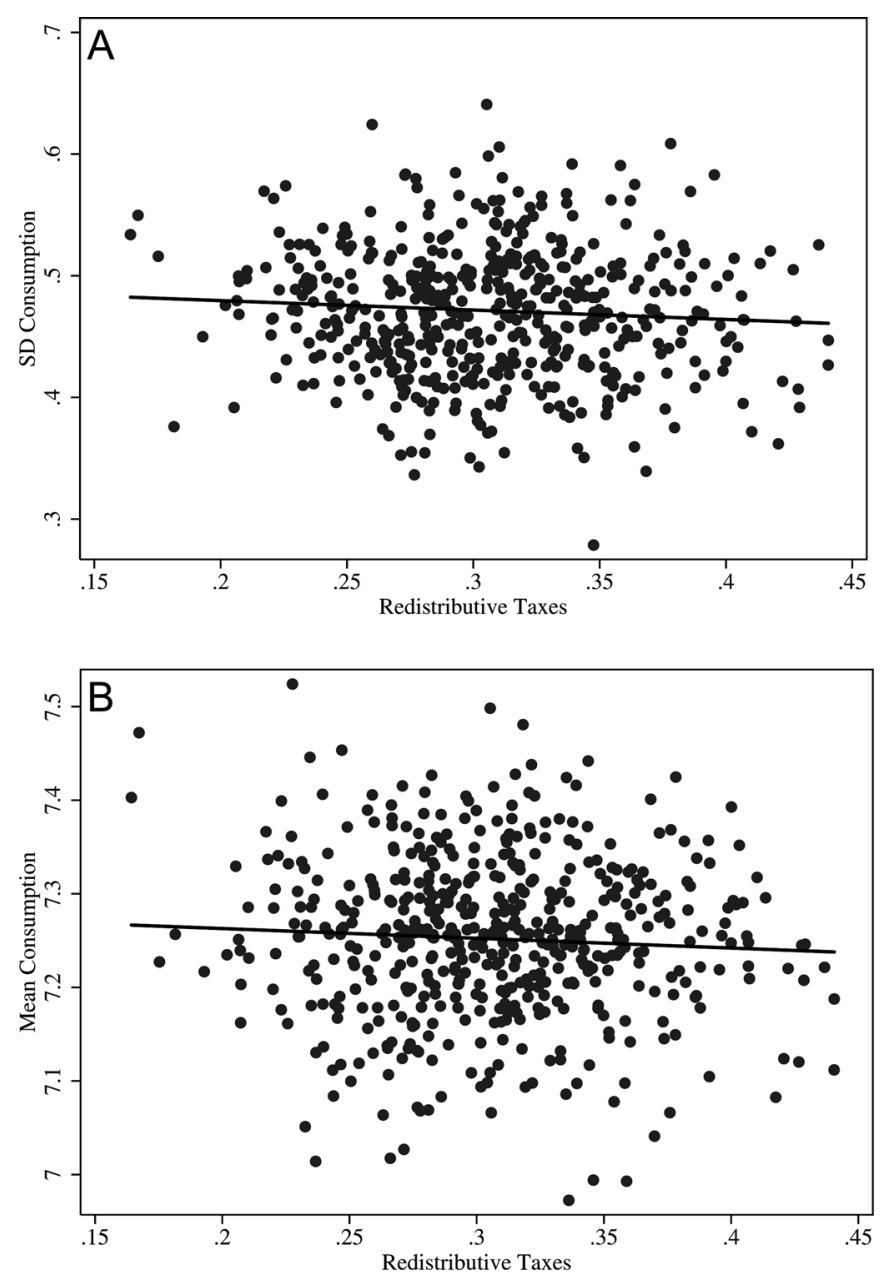

education, family size, month, year, race, and marital status. Group averages were then constructed from the residuals. ${ }^{9}$

Included in the regression are the 22 states for which we had the most household observations. In choosing the cell size (the number of different household observations in each state-year cell), we face a trade-off: choosing a higher number of households in each cell implies fewer observations in the regression, which leads to higher standard errors; in contrast, a smaller cell size generates a larger number of observations in the regression but increases the within-cell sampling error. Either problem makes it more difficult to find a significant result in the regressions. We choose a minimum average cell size of eighty household observations for each state each period. This choice means that 22 states are included in the regressions and seems a reasonable compromise, given that there are few observations for many states.

Figure 1 presents a plot of the raw data of our measure of redistributive taxes and consumption. The upper panel plots the income compression measure of taxes rate against the standard deviation of consumption, the lower against the

\footnotetext{
${ }^{9}$ Omitting these first-stage controls does not substantially change the results.
} 
mean of consumption, with the results reported in column 1 of tables 3 and 4 . The figures look similar when using the mean marginal tax measure (those results are reported in column 5 of tables 3 and 4). In both cases, we have also fitted a regression line through the observations, but while downward sloping, neither slope is significant. The effect on the standard deviation is, however, significant if taxes are measured using the mean marginal tax rate or (as is discussed in the online appendix, available at http://www.mitpressjournals .org/doi/supp1/10.1162/REST_a_00040) the consumption data are trimmed.

The simple regressions shown in figure 1 neglect a number of issues. First, there could be systematic differences across states that obscure or amplify the effects of taxes on consumption. Such differences might depend on differences in the population composition across states and might not be orthogonal to the marginal tax rates. Second, business cycle effects jointly affect income and consumption and therefore have the potential to lie behind the association between taxes and the moments of consumption. Third, state-specific timevarying income risks might affect either the level or the dispersion of consumption. To the extent that tax variables proxy for these risks, one may find a negative association between consumption dispersion and taxes, which may be unrelated to the insurance effect of taxation. Fourth, taxes and consumption might be jointly determined, and therefore our estimates could be affected by a standard endogeneity problem. Therefore, we devote the rest of the paper to understanding how robust the relation is between taxes and consumption. ${ }^{10}$

\section{A. The Insurance Effect of the Tax System}

Table 3 shows the regressions using the standard deviation of $\log$ consumption as the dependent variable. The first five columns report the results when the tax system is measured using our preferred income compression measure, and the last five columns use the mean marginal tax rate. A negative relationship between the tax system and the standard deviation of log consumption when using raw data may partly reflect the fact that many factors affect the level of wealth or taxes in an economy that are unrelated to taxes. To control for this, we include state dummies in all regressions. This removes any fixed differences across states. Columns 2 and 7 report the results for the simplest specification that account for state effects. The coefficients are negative and are also statistically significant at the $5 \%$ and $1 \%$ level.

A further concern with these regressions is that taxes and transfers, and income or consumption shocks, may be codetermined. For example, a positive productivity or income

\footnotetext{
10 We also undertake further robustness checks in the online appendix available at http://www.mitpressjournals.org/doi/suppl/10.1162/REST_ a_00040, which investigates the effect of trimming the data of lowconsumption households (since taking logs could make the data sensitive to low outliers) and using all three months to which each interview in the CEX refers rather than just the month closest to the interview month. We thank two anonymous referees for recommending these checks.
}

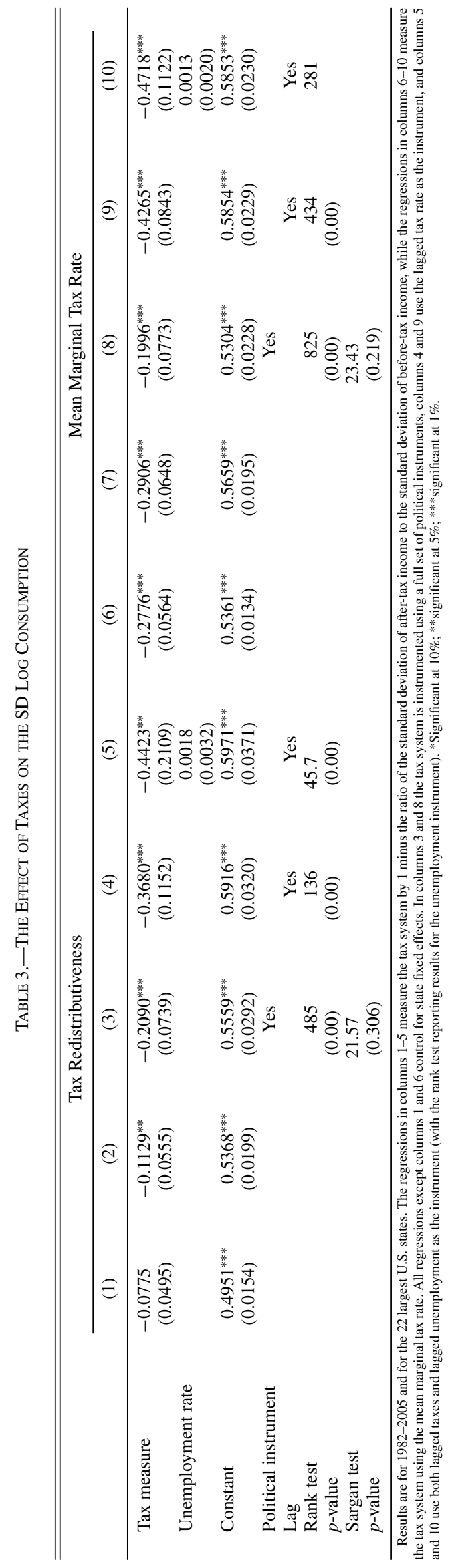




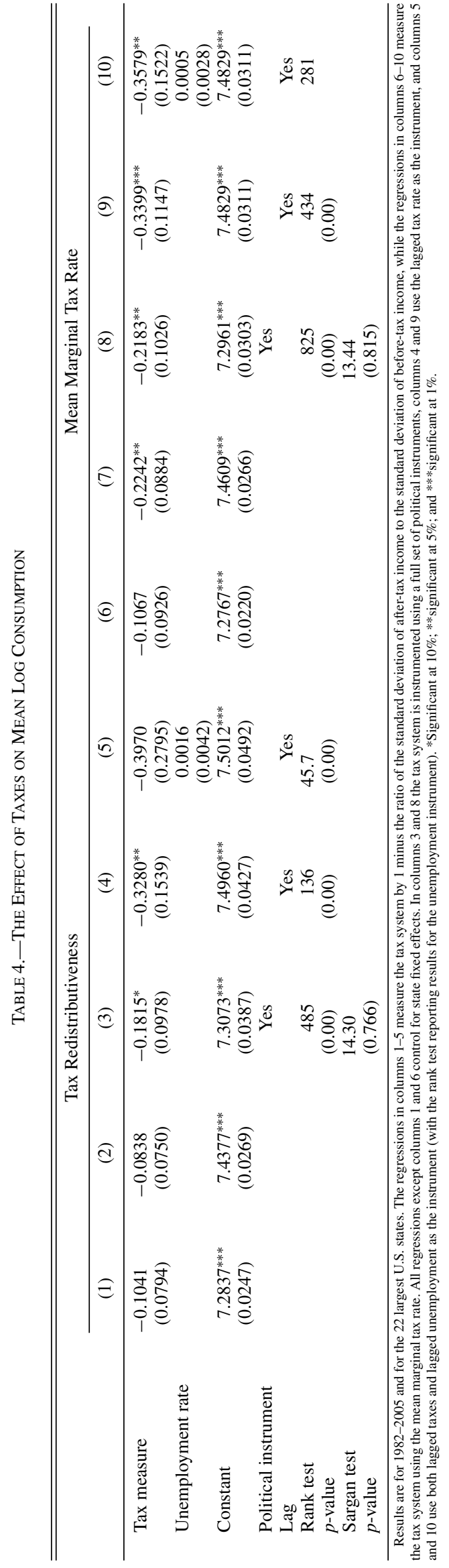

shock to the state is likely to affect the state's budget (and hence tax requirements) as well as households' levels of gross income and consumption in the state. Alternatively, the observed differences across states might come from unobservable heterogeneity in preferences or household attributes at the household level. Other differences may arise from cross-state variation in the underlying idiosyncratic component of the income process at the household level (for example, if social security contributions and benefits are related to household features or employment histories).

Sampling households whose heads are aged between 30 and 60 helps to control for many of the potential problems due to heterogeneity in personal attributes at the household level, as does the inclusion of state dummies. However, potential endogeneity problems could still occur. To address these potential problems, we rely on two different sets of instrumental variables that predict the extent of redistribution through taxes and transfers but do not affect current consumption insurance directly. Our first set of instruments includes lagged values of the redistribution measures. However, it would also be useful to look at a measure of the expected tax system where the expectation depends on the effectiveness of the state administration in raising tax revenue and the likely taste for redistribution of the local residents in the state. We accomplish this by instrumenting the tax system with a set of lagged political variables, and two additional variables: a measure of the tax-raising ability, or tax fiscal capacity of the state in each period and a measure of the tax intensity or effort in each period. We will call the whole instrument set political variables.

For the years up to 1991, data on tax efficiency are available from ACIR (Advisory Commission on Intergovernmental Relations, 1993); data for the subsequent years are taken from Tannenwald (2002) and Tannenwald and Turner (2004), although it was necessary to linearly interpolate the series for some years. More details on these measures are available in Tannenwald (2002). To these two measures we add a set of instruments containing political variables, like the political affiliation of the state governor and the state legislature and the proportion of voters in a state voting Democratic rather than Republican in presidential elections. ${ }^{11}$ Political variables are candidate instruments since they are likely to reflect attitudes toward redistribution, rather than general economic conditions.

Columns 3 and 8 of table 3 investigate the effect of using the political variables, while columns 4 and 9 use the lagged taxes as instruments. For both tax measures and both instrument sets, the rank test is significant. Moreover, the Sargan test does not reject the overidentifying restrictions for the income compression measure (column 3 ) or the mean marginal tax rate measure (column 8). Combining the rank and Sargan tests suggests that the political variables are suitable instruments for a regression of the tax measure on mean

\footnotetext{
11 The data were made available by Tim Storey at the National Conference of State Legislatures.
} 
consumption. The results show that the effect is not only negative for both measures of the tax system, but also significant at the $1 \%$ level for the income compression measure of taxes and at the 5\% level for the mean marginal tax rate for both instrument sets. When lagged taxes (columns 4 and 9) are used, the coefficients are significant at the $1 \%$ level for both tax measures.

As a further test of the theory, we include the state-specific business cycle effects with the state unemployment rate in our regression in columns 5 and 10, instrumented by its lag. Business cycle effects might be state specific and come in the form of time-varying income risk, which affects the consumption distribution. By the same token, such effects might also be correlated with our tax measures. Therefore, our results may stem from not controlling for those effects. The coefficients remain significant at the 5\% level in column 5 , and at the $1 \%$ level in column 10. Moreover, these regressions suggest that as much as a quarter of the difference in inequality between states can be explained by differences in how redistributive the tax system is (that is, the estimated coefficient in the second column would account for a quarter of the difference in equality between the most and the least redistributitive state).

Overall the results suggest that making the tax system more redistributive substantially reduces the standard deviation of consumption, or cross-sectional variability, as we would expect. The evidence presented here points toward a negative relation between taxes and consumption inequality. This finding supports the premise that tax systems provide insurance to households.

\section{B. The Distortionary Effect of the Tax System}

If the tax system has a distortionary effect, then one would expect to observe a negative correlation between taxes and mean consumption. As already stated, the basic regression with no controls, corresponding to figure 1 and reported in the first column of table 4, does not uncover a statistically significant relationship between mean consumption and the mean marginal tax rate. However, as was argued for the standard deviation of consumption results, it is important to account for various types of endogeneity that might affect this conclusion. This analysis is reported in the remaining columns of table 4.

To account for the cross-state differences in the composition of population within each state and for the effect of unobservable variables that might be correlated with taxes, we include state dummies in all regressions of table 4 . The results for the simple specification containing state dummies show that the mean marginal tax rate is now negatively related to mean consumption (column 7), but the redistributiveness measure is not (column 2), suggesting, nevertheless, that a statistically significant negative correlation may be in the data.

We address the endogeneity of the tax variables by instrumenting, as we did for the standard deviation of consumption regressions. For both tax measures, the effect of taxes on mean consumption is large and statistically significant when we instrument with the political variables (columns 3 and 8), and the Sargan test is passed. Similarly significant results are obtained when instrumenting with lagged taxes (columns 4 and 9). When including the state unemployment rate in the regression, only the negative correlation between the mean marginal tax rate and mean consumption is preserved (column 10). The correlation between the redistributiveness measure and mean consumption becomes statistically insignificant in this specification (column 5).

Overall, the results using the mean marginal tax rate in table 4 support the hypothesis that a more redistributive tax system is associated with lower average consumption. However, the results using the income compression measure are less convincing (in two cases, they are not significant at the $10 \%$ level). The evidence thus suggests that the correlation between mean consumption and taxes is negative, though the extent of such correlation and its precision depend on the particular measure of taxes used.

Our results thus confirm how difficult it is to document the distortionary effect of taxes and are consistent with the literature that has tried to estimate the elasticity of taxable income with respect to the marginal tax rate. This line of research, initiated by studies such as Lindsey (1987) and Feldstein (1995), has shown how difficult it is to find empirically a distortionary effect from higher taxation. This inconclusiveness is also similar to more recent findings such as Backus, Henriksen, and Storesletten (2008), who focus on the effect of taxes on global capital allocation and find mixed evidence on the relation between taxes and capital. It seems that investigating the empirical robustness of the theoretically plausible distortionary effect of taxes on consumption is an open question for further future research.

\section{Conclusion}

When consumers face uninsurable, idiosyncratic income risk, redistributive taxes have two countervailing effects: an insurance and a distortionary effect. The first effect is captured by a negative relationship between taxes and consumption dispersion across households. The second effect is shown by a negative relationship between taxes and mean consumption. Hitherto, however, there has been little empirical research into whether we can observe either of these effects in the data, which is perhaps surprising given the prominence and vehemence with which they have been discussed. This may partly be explained by the difficulty in devising an appropriate test. We address this issue by investigating the differences in the mean and standard deviation of log nondurable consumption when the redistributiveness of the tax system varies using household-level data. We take data for income and for consumption from different data sources to eliminate spurious correlation in the state-level tax and consumption measures. Finally, constructing a measure of the redistributiveness of the tax system requires that we account for the fact that households receive transfers and pay 
different effective tax rates. We construct an income compression measure to address these concerns.

The U.S. states provide a suitable laboratory since, perhaps surprisingly, these states vary substantially in the degree to which their tax and benefit systems are redistributive. We find strong supportive evidence for the presence of the insurance effect, as there is a negative correlation between redistributive taxes and the standard deviation of log nondurable consumption. We show that our results are not affected by unobserved heterogeneity at the state level or, for the most part, to nationwide and state-specific business cycle effects. Moreover, accounting for the potential endogeneity of taxes by using appropriate instrumental variables does not alter our conclusions. The negative correlation between redistributive taxes and within-state mean consumption is less resistant to the same robustness checks. However, our results lend support to the empirical relevance of the distortionary effect of redistributive taxation.

In summary, we find strong evidence for the insurance effect of redistributiveness through the taxation system and milder evidence for the distortionary effect of taxation. Taken together, we interpret our findings to suggest that these channels are an empirically relevant consideration for policy analysis. Models with uninsurable idiosyncratic risk, for instance, Aiyagari and McGrattan (1998), Floden (2001), Domeij and Heathcote (2004), and Conesa et al. (2008), thus stress an important issue in the evaluation of policies financed through marginal income taxes.

\section{REFERENCES}

Advisory Commission on Intergovernmental Relations, State Fiscal Capacity and Tax Effort-1991 (Washington, DC: U.S. Government Printing Office, 1993).

Aiyagari, S. Rao, "Uninsured Idiosyncratic Risk and Aggregate Saving," Quarterly Journal of Economics 109:3 (1994), 659-684.

Aiyagari, S. Rao, and Ellen R. McGrattan, "The Optimum Quantity of Debt," Journal of Monetary Economics 42:3 (1998), 447-469.

Attanasio, Orazio P., Erich Battistin, and Hidehiko Ichimura, "What Really Happened to Consumption Inequality In the U.S.?" In E. Berndt and C. Hulten (Eds.), Measurement Issues in Economics: Paths Ahead: Essays in Honour of Zvi Griliches (Chicago: University of Chicago Press, 2005).

Attanasio, Orazio P., and José-Víctor Ríos-Rull, "Consumption Smoothing in Island Economies," European Economic Review 44:7

Backus, David, Espen Henriksen, and Kjetil Storesletten, "Taxes and the Global Allocation of Capital," Journal of Monetary Economics 55:1 (2008), 48-61.
Bewley, Truman F., "Stationary Monetary Equilibrium with a Continuum of Independently Fluctuating Consumers" (pp. 79-102), Werner Hildenbrand and Andreu Mas-Colell (Eds.), in Contributions to Mathematical Economics in Honor of Gerard Debreu (Amsterdam: North-Holland, 1986).

Carroll, Christopher D., "Buffer Stock Saving and the Life Cycle/ Permanent Income Hypothesis," Quarterly Journal of Economics 112:1 (1997), 1-56.

Conesa, Juan Carlos, Sagiri Kitao, and Dirk Krueger, "Taxing Capital? Not a Bad Idea After All,’ American Economic Review 99:1 (2009), $25-48$.

Deaton, Angus, "Saving and Liquidity Constraints," Econometrica, 59:5 (1991), 1221-1248.

Domeij, David, and Jonathan Heathcote, "On the Distributional Effects of Reducing Capital Taxes," International Economic Review 45:2 (2004), 523-554.

Elmendorf, Douglas W., and Miles Kimball, "Taxation of Labor Income and the Demand for Risky Assets," International Economic Review 41:30 (2000), 801-832.

Feenberg Daniel R., and Elisabeth Coutts, "An Introduction to the TAXSIM Model," Journal of Policy Analysis and Management 12:1 (1993), 189-194.

Feenberg Daniel R., and Harvey S. Rosen, "State Personal Income and Sales Taxes: 1977-1983," NBER working paper no. 1631 (1987).

Feldstein, Martin, "The Effect of Marginal Tax Rates on Taxable Income: A Panel Study of the 1986 Tax Reform Act," Journal of Political Economy 103:3 (1995), 551-572.

Floden, Martin, "The Effectiveness of Government Debt and Transfers as Insurance," Journal of Monetary Economics, 48:1 (2001), 81-108.

Gourinchas, Pierre-Olivier, and Jonathan Parker, "Consumption over the Life Cycle," Econometrica 70:1 (2002), 47-90.

Hubbard, Glenn, Jonathan Skinner, and Stephen Zeldes, "Precautionary Saving and Social Insurance," Journal of Political Economy 103:2 (1995), 360-399.

Huggett, Mark, "The Risk-Free Rate in Heterogeneous-Agent IncompleteInsurance Economies," Journal of Economic Dynamics and Control 17:5-6 (1993), 953-969.

Krueger, Dirk, and Fabrizio Perri, "Public verus Private Risk-sharing," University of Minnesota, working paper (2006).

Lindsey, Lawrence B., "Individual Taxpayer Response to Tax Cuts: 1982 1984, with Implications for the Revenue Maximizing Tax Rate,' Journal of Public Economics 33 (1987), 173-206.

Mirrlees, James, "Notes on Welfare Economics, Information and Uncertainty," in M. Balch, D. McFadden, and S. Wu (Eds.), Essays on Economic Behaviour under Uncertainty (Amsterdam: North-Holland, 1974).

Ruser, John W., Adrienne T. Pilot, and Charles Nelson, "Alternative Measures of Household Income: BEA Personal Income, CPS Money Income and Beyond," paper presented at the FESAC meeting, December 14, 2004.

Tannenwald, Robert, "Interstate Fiscal Disparity in 1997," New England Economic Review Q3 (2002), 17-33.

Tannenwald, Robert, and Nicholas Turner, "Interstate Fiscal Disparity in State Fiscal Year 1999," Public policy discussion paper 04-9, Federal Reserve Bank of Boston (2004).

Varian, Hal R., "Redistributive Taxation as Social Insurance," Journal of Public Economics 14 (1980), 49-68. 